\title{
Characterization of Eu(III) Complex for Determination of Bumetanide in Pharmaceutical Preparations and in Biological Fluids
}

\author{
M. M. Abd-Elzaher ${ }^{1 *}$, Mona. A. Ahmed ${ }^{2}$, A. B. Farag ${ }^{3}$, \\ M.S. Attia ${ }^{4}$, A. O. Youssef ${ }^{4}$ and Sh. M. Sheta ${ }^{1}$ \\ ${ }^{1}$ Inorganic Chemistry Department, National Research \\ Centre, 33, El-Behouth St., Dokki, Giza, ${ }^{2}$ Department of \\ Chemistry, College of Women for Art, Science and \\ Education, Ain Shams University, Cairo, ${ }^{3}$ Department of \\ Chemistry, Faculty of Science, Helwan University, Helwan \\ and ${ }^{4}$ Department of Chemistry, Faculty of Science, Ain \\ Shams University, Cairo, Egypt.
}

WU(III)-Acetylacetone complex 1 was prepared and characterized by elemental analysis, UV/Vis, IR, ${ }^{1} \mathrm{H}-\mathrm{NMR}$ spectroscopy, conductance and magnetism. The spectral results indicated that the composition of this complex is $\left[\mathrm{Eu}(\mathrm{acac})_{2}\left(\mathrm{NO}_{3}\right)(\mathrm{EtOH})_{2}\left(\mathrm{H}_{2} \mathrm{O}\right)_{2}\right]$.We development simple, sensitive and selective spectrofluorimetric method for the determination of trace amounts of bumetanide in pharmaceutical tablets and biological fluids (serum and urine) using complex 1 . The bumetanide can remarkably enhance the fluorescence intensity of the complex in acetonitrile at $\lambda_{\text {ex/Em }}=385 / 619 \mathrm{~nm}$ and $\mathrm{pH}$ 7.1. The dynamic ranges for the determination of bumetanide concentration were found from $1 \times 10^{-11}$ to $1 \times 10^{-4} \mathrm{~mol} \mathrm{~L}^{-1}$, and the limit of detection (LOD) and quantitation limit of detection (LOQ) are $1.6 \times 10^{-10}$ and $3.2 \times 10^{-9} \mathrm{~mol} \mathrm{~L}^{-1}$, respectively.

Keywords: Acetylacetone, Europium, Complex, Characterization, Bumetanide, Spectrofluorimetric, Fluorescence intensity.

Bumetanide [chemical name: 3-Butylamino-4-phenoxy-5sulphamoylbenzoic acid] (Fig. 1) is considered one of loop diuretic group and used in the treatment of hypertension, and oedema associated with heart failure and with renal and hepatic disorders ${ }^{(1-3)}$. 
<smiles>CCCCNc1cc(C(=O)O)cc(S(N)(=O)=O)c1Oc1ccccc1</smiles>

Fig. 1. Chemical structure of bumetanide.

A marked dieresis is additionally associated to loss of weight (rapidly lower body weight), so it's abused in sports that weight classes are concerned. Fast and intense dieresis hides the ingestion of other doping drugs by dilution of their concentration in urine samples ${ }^{(4)}$. The World Anti-Doping Agency (WADA) (Medical Commission of the International Olympic Committee) has forbidden the use of bumetanide in 1986 for this reason ${ }^{(5)}$.

Due to clinical wide use of bumetanide, different analytical methods to determine bumetanide in pharmaceuticals preparations and biological fluids have been improved $(6,7)$. The methods like spectrophotometry ${ }^{(8,9)}$, variable-angle scanning fluorescence spectrometry ${ }^{(10)}$, spectrofluorimetry ${ }^{(11-12)}$, potentiometry ${ }^{(13)}$, voltammetry ${ }^{(14)}$ and chromatography ${ }^{(15-17)}$. were used. However, most of these methods are time-consuming and technically demanding and So, we need an alternative method simple, low-cost, sensitive and rapid for the determination of bumetanide in pharmaceuticals preparations and biological samples.

The europium complexes are very important, because of the saturated red emission resulting from emitting strong fluorescence arising from $\mathrm{f}-\mathrm{f}$ hyper sensitive transition with a large Stokes shift and long lifetime ${ }^{(18)}$. The distinguished properties of the europium complexes enabled the development of a fluorescence chemical sensor with high sensitivity. According to Laporte rule, the $4 \mathrm{f}-4 \mathrm{f}$ transitions in rare earth ions are forbidden to some extent; so the absorption and emission spectra observed in the Eu(III) ions have always weak intensity. The excited states of the $\mathrm{Eu}(\mathrm{III})$ ions may increase by its coordination to organic ligands, which act as sensitizers, and the ligands that have this property are called by Lehn 
“antennas" (19) . The organic ligand in Eu(III)-complex absorbs and transfers energy efficiently to the metal ion and increases its luminescence intensity consequently.

In this article an $\mathrm{Eu}(\mathrm{III})$-acetylacetone complex 1 was prepared and characterized using different spectroscopic techniques, then used in determination of bumetanide in pharmaceuticals and biological samples (serum and urine).

\section{Chemicals and reagents}

\section{Experimental}

All chemicals used were of analytical reagents grade obtained from Aldrich Chemical Company (USA). The drug standard (bumetanide) was obtained from Sigma-Aldrich. The pharmaceutical preparations containing the drugs obtained from local drug stores. Urine and serum samples were obtained from healthy volunteers during morning hours.

\section{Instruments}

Elemental analyses were carried out in Cairo University, Egypt. The IR spectra of the ligand and solid complex were recorded as $\mathrm{KBr}$ discs using JASCO FT/IR-460 infrared spectrophotometer. The electronic spectra (200$900 \mathrm{~nm})$ were carried out using a Perkin-Elmer 550 spectrophotometer. The ${ }^{1} \mathrm{H}-\mathrm{NMR}$ spectra in deutrated dimethylsulfoxid (DMSO) as a solvent and were recorded on Gemini-300 $\mathrm{MHz}$ NMR spectrometer. The molar conductance of $10^{-3} \mathrm{M}$ solution of metal complex in DMSO was measured on a dip cell and a Bibby conductimeter MC1 conductivity meter model. A magnetic measurement of the solid complex was measured at room temperature using Gouy's method by a magnetic susceptibility balance from Johnson Metthey and Sherwood model. The fluorescence measurements were carried out on a Shimadzu RF5301 spectrofluorophotometer in the range $290-750 \mathrm{~nm}$.

\section{Procedures}

\section{General procedure}

$\mathrm{Eu}(\mathrm{III})$-Acetylacetone complex 1 , was synthesized by mixing $20 \mathrm{ml}$ aliquot of $1 \times 10^{-2} \mathrm{M}$ of the ligand with a $10 \mathrm{ml}$ aliquot of $1 \times 10^{-2} \mathrm{M} \mathrm{Eu}(\mathrm{III})$ nitrate (2:1 ligand to metal molar ratio) with stirring. The mixture was refluxed at about $80^{\circ} \mathrm{C}$ for two hours; then the mixture was cooled to $0^{\circ} \mathrm{C}$. The resulting precipitate of the complex 1 is greenish yellow; the resulting precipitate of the complex was filtered off, and washed.

To $10 \mathrm{ml}$ clean measuring flasks, the standard solution of bumetanide was prepared by different additions of $1 \times 10^{-3} \mathrm{~mol} \mathrm{~L}^{-1}$ drug stock solution to give the following concentrations of the drug, $1 \times 10^{-4}$ to $1 \times 10^{-12} \mathrm{~mol} \mathrm{~L}^{-}$ 
1. The solutions were diluted to the mark with DMSO or acetonitrile or methanol or deionized water at room temperature. The above solutions were used for subsequent measurements of absorption and emission spectra as well as the effect of solvents and $\mathrm{pH}$. The fluorescence intensities were measured at $\lambda_{\mathrm{ex}} / \lambda_{\mathrm{em}}=385 / 619$.

\section{Determination of bumetanide in pharmaceutical preparations}

Ten tablets of bumetanide were carefully weighed and ground to finely divided powders. Accurate weights equivalent to $1.0 \mathrm{mg}$ bumetanide was dissolved in $50 \mathrm{ml}$ acetonitrile and mixed well and filtered up using $12 \mathrm{~mm}$ filter papers. The concentration of the drug was determined by using different concentrations from the corresponding calibration graph.

\section{Determination of bumetanide in serum samples}

A $1.0 \mathrm{ml}$ of samples of blood collected from various healthy volunteers was centrifuged for $15 \mathrm{~min}$ at $4500 \mathrm{r} / \mathrm{min}$ to remove proteins. The unknown amount of drug in human serum samples was determined using the standard addition (spiking) techniques.

\section{Determination of bumetanide in urine samples}

The urine samples studied, which were obtained from healthy male and female volunteers who had taken no drug previously, were processed in the laboratory as follows: $10 \mathrm{ml}$ of urine were centrifuged for $15 \mathrm{~min}$ at 4500 $\mathrm{r} / \mathrm{min}$ to remove precipitate salts, crystals, pus cells, and red blood cells (RBCs). A $1.0 \mathrm{ml}$ of urine was supplied with the volume of drug solutions. The unknown amount of drug in human urine samples was determined using the standard addition (spiking) techniques.

\section{Analytical performance and method validation}

The Analytical performance and validation of the method is carried out by studding the following parameters:

A. Calibration curve : A linear correlation was found between

fluorescence intensity of the $\mathrm{Eu}(\mathrm{III})$-Acetylacetone complex at $\lambda_{\mathrm{em}}=619$ $\mathrm{nm}$ and concentration of bumetanide. The obtained calibration curve and the graph were described by the regression equation:

$$
\mathrm{Y}=\mathrm{a}+\mathrm{bX}
$$

(where $\mathrm{Y}=$ fluorescence intensity of the sensor at $\lambda_{\mathrm{em}}=619 \mathrm{~nm} ; \mathrm{a}=$ intercept; $\mathrm{b}=$ slope and $\mathrm{X}=$ concentration in $\mathrm{mol} \mathrm{L}^{-1}$ ).

Regression analysis of bumetanide intensity data using the method of least square was made to evaluate the slope (b), intercept (a) and correlation 
coefficient (r). The limit of detection (LOD) and quantitation (LOQ) calculated according to ICH guidelines ${ }^{(31,32)}$ using the formulae:

$$
\mathrm{LOD}=3.3 \mathrm{~S} / \mathrm{b} \text { and } \mathrm{LOQ}=10 \mathrm{~S} / \mathrm{b}
$$

(where $\mathrm{S}$ is the standard deviation of blank fluorescence intensity values, and $b$ is the slope of the calibration plot).

B. Accuracy and precision of the method: To compute the accuracy and precision, the assays described under "general procedures" were repeated three times within the day to determine the repeatability (intraday precision) and three times on different days to determine the intermediate precision (inter-day precision) of the method. These assays were performed for three levels of analyte. The low percentage relative standard deviation (\%RSD) values (intra-day) and (inter-day) indicating high precision of the method. The accuracy of the method is evaluated as percentage relative error (RE) between the measured mean concentrations and the taken concentrations of bumetanide. Bias \{ bias \% $=[($ Concentration found - known concentration $) \times 100 /$ known concentration]\} is also calculated.

C. Selectivity: The proposed methods were tested for selectivity by placebo blank and synthetic mixture analysis. A placebo blank containing talc $(250 \mathrm{mg})$, starch $(300 \mathrm{mg})$, lactose $(30 \mathrm{mg})$, calcium carbonate $(50 \mathrm{mg})$, calcium dihydrogen orthophosphate $(20 \mathrm{mg})$, methyl cellulose $(40 \mathrm{mg})$, sodium alginate $(70 \mathrm{mg})$ and magnesium stearate $(100 \mathrm{mg})$ was extracted with water and solution made as described under " analysis of dosage forms". A convenient aliquot of solution was subjected to analysis according to the recommended procedures. In the method of analysis, there was no interference by the inactive ingredients.

A separate test was performed by applying the proposed method to the determination of bumetanide in a synthetic mixture. To the placebo blank of similar composition, different amount of bumetanide of different products were added, homogenized and the solution of the synthetic mixture was prepared as done under "analysis of dosage forms". The filtrate was collected in a $100 \mathrm{ml}$ flask. Five $\mathrm{ml}$ of the resulting solution was assayed $(n=3)$ by proposed method and then calculate the recovery percent.

D. Application to formulations: The proposed methods were applied to the determination of bumetanide in Burinex tablets $1.0 \mathrm{mg}$ (minapharm Com.) which is purchased from local market and containing other inactive ingredients and in serum and urine samples of the health state human. 
E. Recovery study: To further assess the accuracy of the methods, recovery experiments were performed by applying the standard-addition technique. The recovery was assessed by determining the agreement between the measured standard concentration and added known concentration to the sample. The test was done by spiking the preanalysed tablet powder with pure bumetanide at three different levels $(0.1,1.0$ and $10.0 \mathrm{n} \mathrm{mol} \mathrm{L}-1)$ of the content present in the tablet powder (taken) and the total was found by the proposed method. Each test was repeated three times.

\section{Results and Discussion}

Characterizations of the Eu(III) Acetylacetone complex 1

The electronic absorption spectra of the prepared complex 1 and acetylacetone compounds were measured in ethanol at room temperature. Spectra data of the ligand and complex are represented in Table 1. Uv/Vis spectra of the $\mathrm{Eu}(\mathrm{III})$ complex showed an absorption band (intense highenergy) at about $218 \mathrm{~nm}$. These high-energy absorption bands are assigned to $\mathrm{n}-\pi^{*}$ and $\pi-\pi^{*}$ transition in the complex ${ }^{(20)}$.

The IR spectrum of complex 1 was summarized in Table 1 . The stretching band at $1637 \mathrm{~cm}^{-1}$ found in the ligand L1 was appointed to the $\mathrm{C}=\mathrm{O}$ group, and this stretching band shifted to decrease energy by $15 \mathrm{~cm}^{-1}$ in complex 1. This result may be due to the resonance of the deprotonated anion which affords the $\mathrm{C}=\mathrm{O}$ bonds the mixed character of single and double bonds. This shift confirmed L1 also the participation of the carbonyl group in the complexation with Eu(III) ion ${ }^{(2)}$. The IR absorption bands appeared at $1176,783 \mathrm{~cm}^{-1}$ for L1; which resulting from the in-plane and out-of-plane vibrations of C-H bonds. These bands were shifted $\left(26-38 \mathrm{~cm}^{-}\right.$ ${ }^{1}$ ) by complexation, and these changes could be attributed to the change in rigidity of the ligand ring due to complexation ${ }^{(20) .}$ In complex 1 a broad band appeared in the range $3000-3600 \mathrm{~cm}^{-1}$ assigned to the water molecules and/or to the $\mathrm{OH}$ stretching vibration of the ligands and/or the ethanol molecules present in the complex ${ }^{(22-24)}$. The new bands at $505 \mathrm{~cm}^{-1}$ observed in complex 1 were attributed to $\mathrm{M}-\mathrm{O}$ bond in complex $1^{(25-32)}$.

The ${ }^{1} \mathrm{H}-\mathrm{NMR}$ spectra of the ligand $\mathrm{L} 1$, and Eu(III)-complex 1 were measured in DMSO- $\mathrm{d}_{6}$ at room temperature. The chemical shift data are given in Table 1, but unfortunately we could not obtain good spectra for the complex which may be due to highly paramagnetic properties of the complex. This adds difficulty to assigning the NMR peaks. 
The molar conductivity of $1 \times 10^{-3} \mathrm{M}$ solution of the metal complex 1 in DMSO at room temperature was found to be $32.52 \mathrm{ohm}^{-1} \mathrm{~cm}^{2} \mathrm{~mol}^{-1}$ (Table 2 ) indicating that the complex is nonelectrolytic in nature ${ }^{(24,25)}$. The magnetic moment value of complex 1 was measured using Gouy method and was found 3.12 B.M (Table 2). The Eu(III) ions were paramagnetic due to their $4 \mathrm{f}$-electrons that were effectively shielded by $5 \mathrm{~s}^{2} 5 \mathrm{p}^{6}$ electrons ${ }^{(24)}$.

The elemental analysis of the complex is consistent with the calculated results from the empirical formula (Table 2). The results indicated that complex 1 is ten-coordinated.

TABLE 1. Electronic absorption, IR, and ${ }^{1} \mathrm{H}-\mathrm{NMR}$ data of the ligand and $\mathrm{Eu}(\mathrm{III})-$ complex.

\begin{tabular}{|c|c|c|c|c|c|c|}
\hline \multirow{2}{*}{$\begin{array}{l}\text { Ligand/ } \\
\text { Complex }\end{array}$} & \multirow{2}{*}{$\begin{array}{c}\text { Absorpti } \\
\text { on Bands } \\
(\lambda) \mathrm{nm}\end{array}$} & \multicolumn{4}{|c|}{ IR spectral data } & \multirow{2}{*}{$\begin{array}{c}{ }^{1} \mathrm{H} \text { NMR } \\
\text { pMSO-d }\end{array}$} \\
\hline & & $\begin{array}{c}\boldsymbol{v}_{\mathrm{C}}= \\
\mathbf{o}\end{array}$ & $\begin{array}{c}\boldsymbol{\delta}_{\mathrm{C}-\mathrm{H}} \\
\text { (in } \\
\text { plane) }\end{array}$ & $\begin{array}{l}\boldsymbol{\delta}_{\mathrm{C}-\mathrm{H}} \\
\text { (out of } \\
\text { plane) }\end{array}$ & $v_{\text {Eu -O }}$ & \\
\hline L1 & 238,274 & 1637 & 1176 & 783 & $\ldots \ldots$ & $\begin{array}{l}2.01\left(\mathrm{~S}, 6 \mathrm{H}, 2 \mathrm{CH}_{3}\right), 2.08 \\
\left(\mathrm{~S}, 6 \mathrm{H}, 2 \mathrm{CH}_{3}\right), 3.80(\mathrm{~S}, 2 \mathrm{H}, \\
\left.\mathrm{CH}_{2} \text { Keto form }\right), 5.69(\mathrm{~S}, \mathrm{H}, \\
\mathrm{CH} \text {-enol form }), 15.61(\mathrm{~S}, \mathrm{H}, \\
\mathrm{OH})\end{array}$ \\
\hline 1 & 218 & 1622 & 1150 & 745 & 505 & $\begin{array}{l}2.51(\mathrm{~m}, 6 \mathrm{H}, 2 \mathrm{CH} 3), 3.35 \\
(\mathrm{~S}, 2 \mathrm{H}, \mathrm{CH} 2)\end{array}$ \\
\hline
\end{tabular}

TABLE 2. Conductivity, magnetism and elemental analysis of complex 1.

\begin{tabular}{|c|c|c|c|c|c|c|}
\hline \multirow{2}{*}{ Complex } & \multirow{2}{*}{$\begin{array}{c}\text { Formula } \\
\text { (formula } \\
\text { weight) }\end{array}$} & \multicolumn{3}{|c|}{ Calcd. (found) } & \multirow{2}{*}{$\begin{array}{c}\operatorname{Am}\left(\Omega^{-1}\right. \\
\left.\mathbf{c m}^{2} \mathbf{m o l}^{-1}\right)\end{array}$} & \multirow[b]{2}{*}{$\mu_{\text {eff }}($ B.M. $)$} \\
\hline & & $\mathbf{C}$ & $\mathbf{H}$ & $\mathbf{N}$ & & \\
\hline 1 & $\begin{array}{c}\mathrm{C}_{14} \mathrm{H}_{34} \mathrm{EuNO}_{11} \\
(544.38)\end{array}$ & $\begin{array}{c}30.89 \\
(30.67)\end{array}$ & $\begin{array}{c}6.30 \\
(6.47)\end{array}$ & $\begin{array}{c}2.57 \\
(2.43)\end{array}$ & 32.52 & 3.12 \\
\hline
\end{tabular}

From the physical and spectral data of the complex 1 discussed above, we can deduce that the metal ions are bonded to two molecules of the ligand as well as one molecule of the nitrate ion and two molecules of water and two molecules of ethanol. Complex 1 may take the formula $\left[\mathrm{Eu}(\mathrm{acac})_{2}\right.$ $\left.\left(\mathrm{NO}_{3}\right)(\mathrm{EtOH})_{2}\left(\mathrm{H}_{2} \mathrm{O}\right)_{2}\right]$, as illustrated in Fig. $2^{(20,26)}$. 
Determination of bumetanide using Eu(III) complex 1 by spectrofluorimetric method Spectral characteristics

A. Absorption spectra: The absorption spectrum of bumetanide is showed in Fig. 3. Threshold two bands at $266 \mathrm{~nm}$ and band at $352 \mathrm{~nm}$ appeared and can be attributed to $n-\pi^{*}$ and $\pi-\pi^{*}$ transitions. The absorbance is also enhanced, by increasing the concentration of the bumetanide.

B. Emission and excitation spectra: Figure 4 represents the emission and excitation spectra of bumetanide (spectrum 1), and that of $\mathrm{Eu}^{3+}$ ions (spectrum 2) and that of complex (1) $\left[\mathrm{Eu}^{3+}\right.$-Acetylacetone] (spectrum 3), and bumetanide-Eu ${ }^{3+}$-Acetylacetone (spectrum 4). From the spectra in Fig. 4, it was concluded that $\mathrm{Eu}^{3+}$ ion has two very weak peaks. Comparing spectrum 1 with spectrum 3 [after the addition of bumetanide into the $\mathrm{Eu}^{3+}$-Acetylacetone], the results showed that bumetanide can form a new complex with $\mathrm{Eu}^{3+}$-Acetylacetone. It can be observed that the characteristic peak of $\mathrm{Eu}^{3+}$ at $619 \mathrm{~nm}$ has been increased remarkably by addition of bumetanide. This is an evidence that bumetanide enhances the energy of bumetanide-Eu ${ }^{3+}$-Acetylacetone complex.

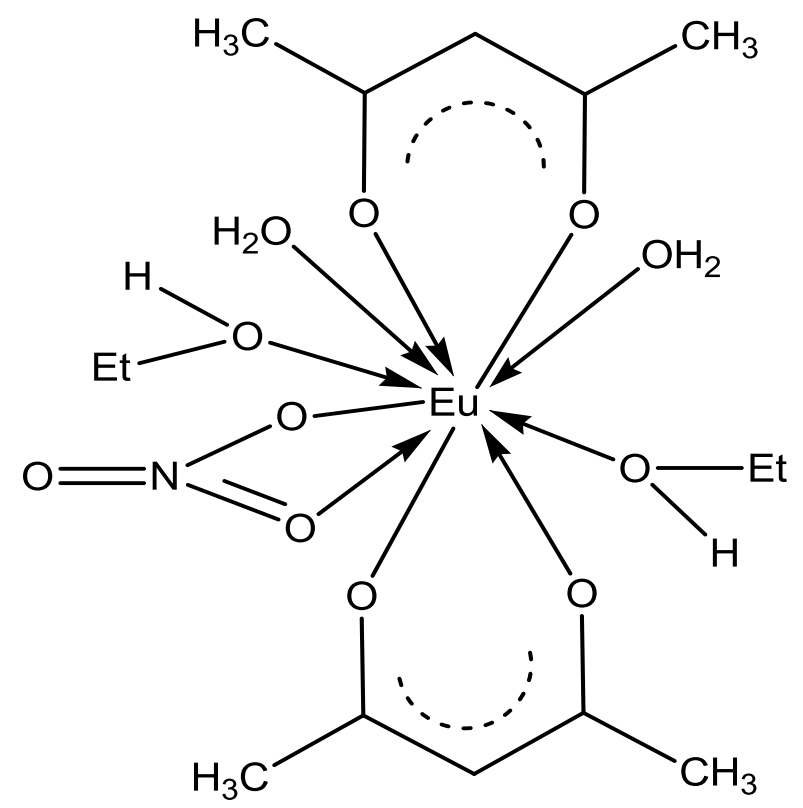

Fig. 2. Structural representation of complex 1. 


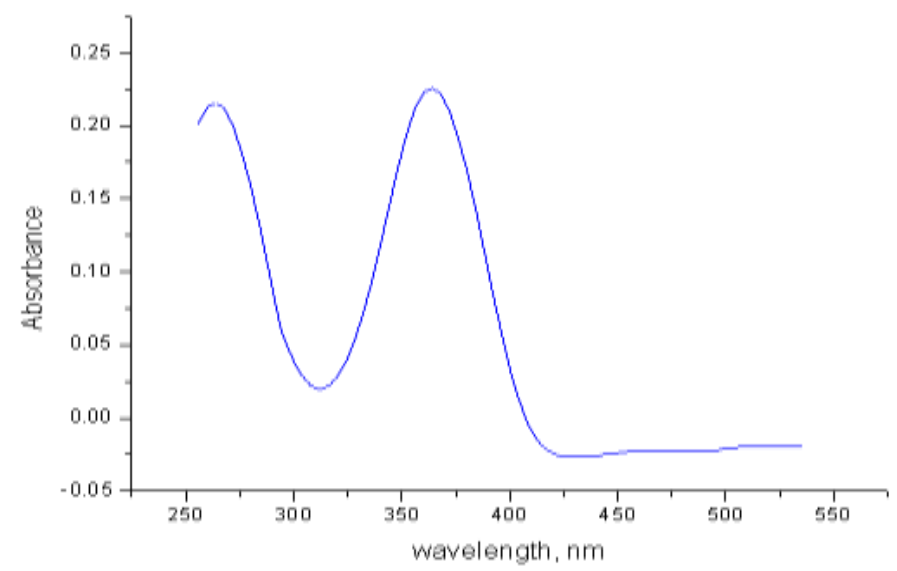

Fig. 3. The absorption spectrum of bumetanide .

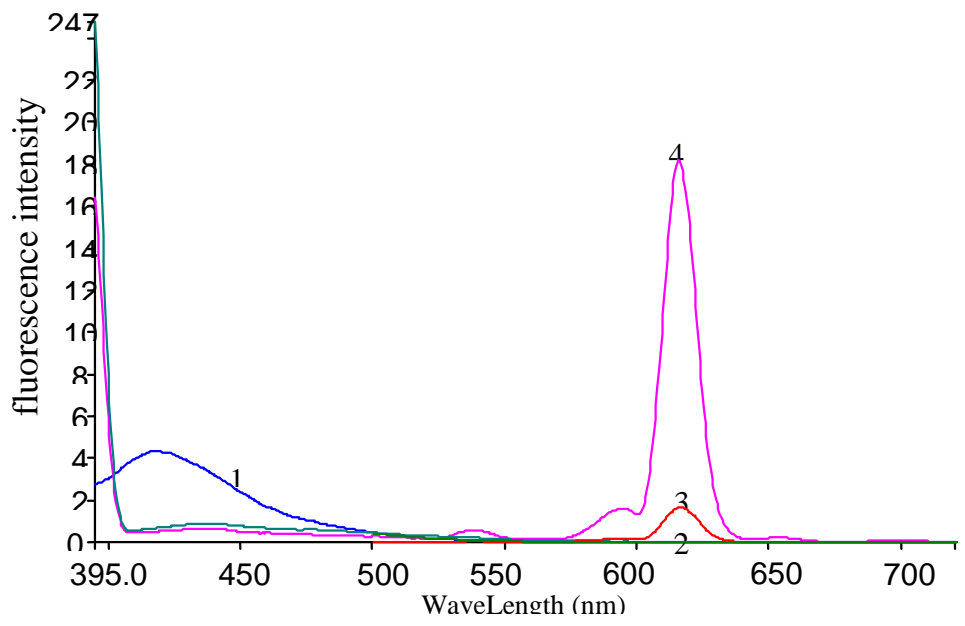

Fig. 4. The fluorescence spectra of (1) the bumetanide, (2) $\mathrm{Eu}^{3+} \mathrm{ion},(3) \mathrm{Eu}^{3+}$ Acetylacetone and (4) bumetanide- $\mathrm{Eu}^{3+}$-Acetylacetone complex .

\section{Experimental parameter effect}

A. $p H$ effect : The fluorescence intensity and absorption spectrum of the bumetanide depend on $\mathrm{pH}$ medium which adjusted using $\mathrm{NH}_{4} \mathrm{OH}$ and $\mathrm{HCl}$. The highest intensity peak which appears at $619 \mathrm{~nm}$ was obtained at $\mathrm{pH}=7.1$.

B. Solvent effect: The fluorescence intensity of the bumetanide was measured in different solvents. From the results we found that in the presence of 
acetonitrile there is no quenching in the emission intensity of bumetanide (Fig. $5)$.

C. Bumetanide concentration effect: The bumetanide-concentrations effect on the fluorescence intensities of the $\mathrm{Eu}^{3+}$-Acetylacetone complex was investigated. The emission spectra of the $\mathrm{Eu}^{3+}$-Acetylacetone gives a characteristic band at $617 \mathrm{~nm}$ after excitation at $385 \mathrm{~nm}$ and the fluorescence intensity was enhanced by increasing the concentration of the bumetanide till $1 \mathrm{x}$ $10^{-4} \mathrm{~mol} \mathrm{~L}^{-1}$ then it became constant in the acetonitrile preparations (Fig. 6).

\section{Method validation}

1. Calibration curve: A linear relationship between fluorescence intensity of the $\mathrm{Eu}(\mathrm{III})$-Acetylacetone complex at $\lambda_{\mathrm{em}}=619 \mathrm{~nm}$ and bumetanideconcentration in the ranges are given in Table 3 . The eleven-point $\left(1 \times 10^{-4}-\right.$ $1 \times 10^{-11}$ ) calibration curve was obtained (Fig. 7). Table 3 presented regression analysis of bumetanide intensity data, whereas Table 4 contained a comparison of spectrofluorimetric technique with some published methods and from Table 4 we noted that the low value of LOD indicates the high sensitivity of our present method for the determination of bumetanide compared with the previous

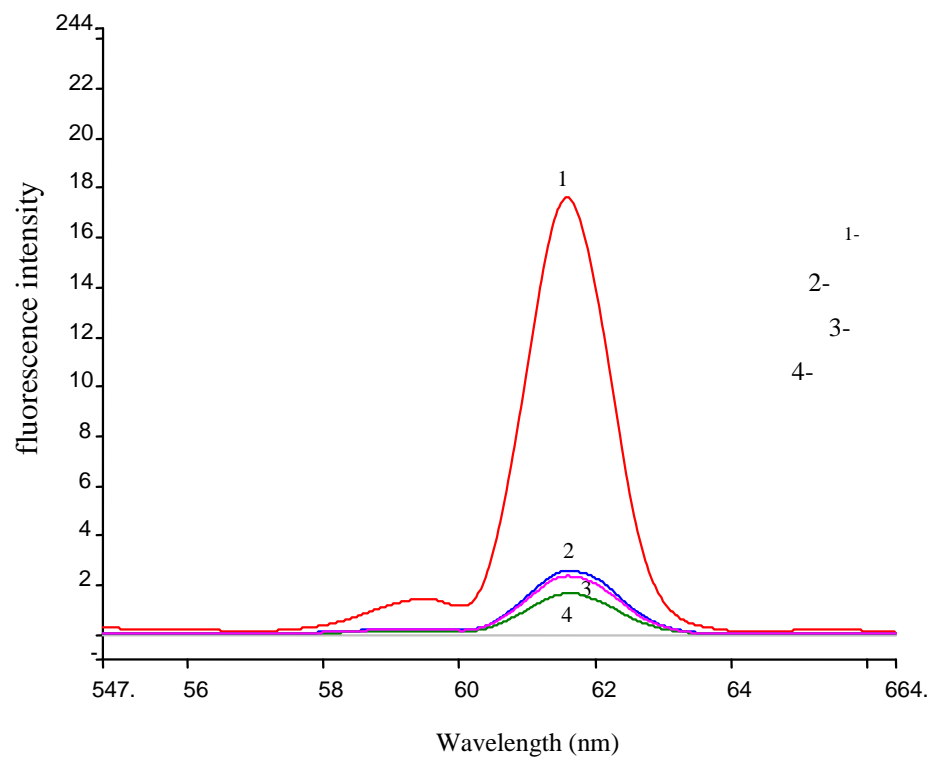

methods. 
Fig. 5. The fluorescence spectra of $1 \times 10^{-5} \mathrm{M}$ of Bumetanide measured in different

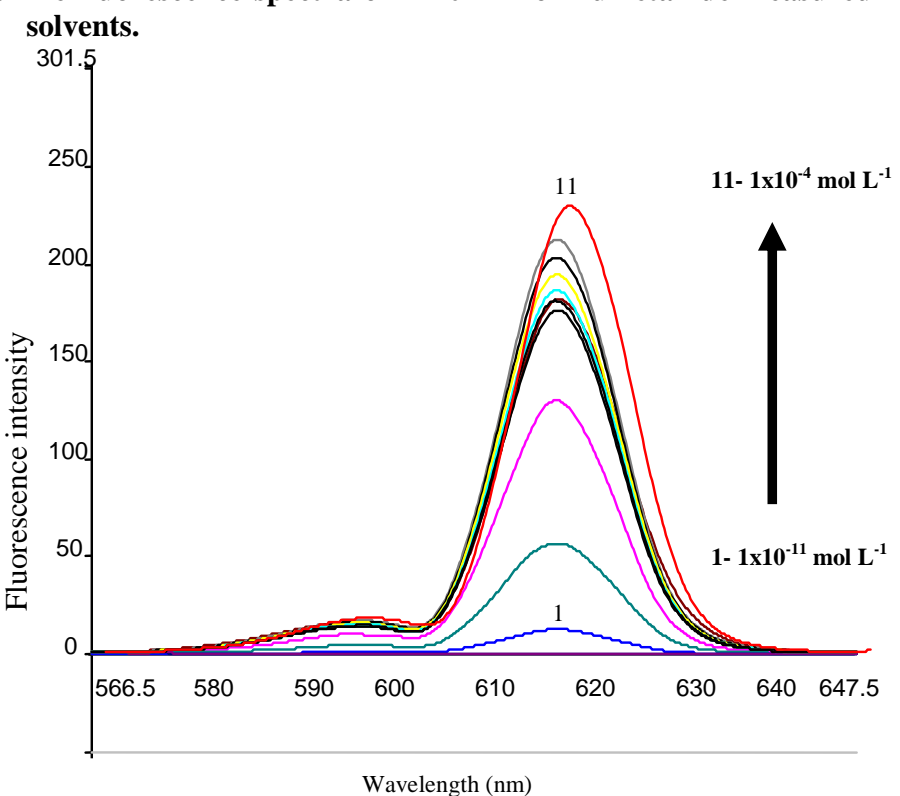

Fig.6. The fluorescence spectra of the Eu(III)-Acetylacetone at different concentrations of bumetanide in acetonitrile. at $\lambda_{\mathrm{ex}}=385 \mathrm{~nm}$ and $\mathrm{pH}$ 7.1.

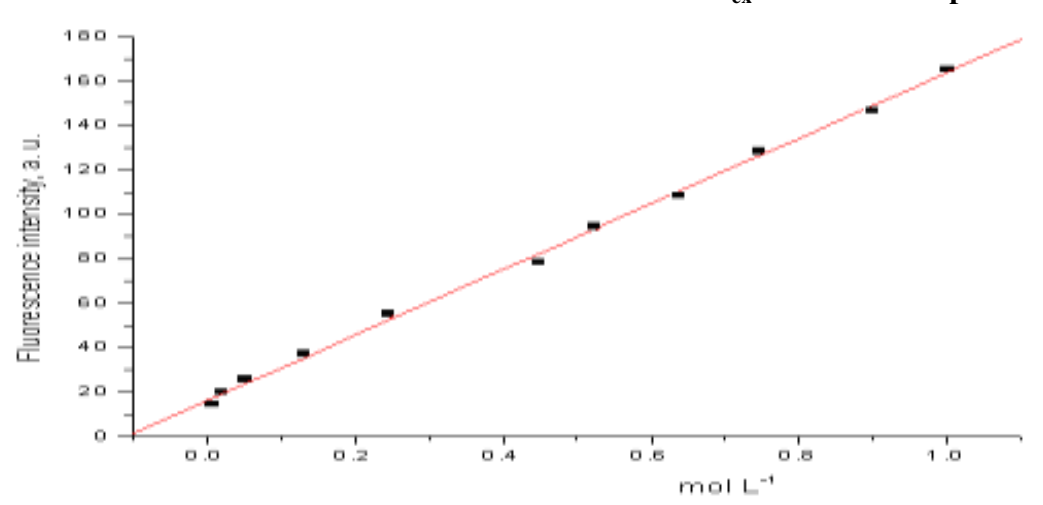

Fig. 7. linear relationship between concentration of bumetanide and fluorescence intensity of $\mathrm{Eu}^{3+}$-Acetylacetone complex in acetonitrile . 
TABLE 3. Sensitivity and regression parameters for the method.

\begin{tabular}{|l|l|}
\hline \multicolumn{1}{|c|}{ Parameter } & \multicolumn{1}{c|}{ Method } \\
\hline$\lambda_{\text {em }} \mathrm{nm}$ & 619 \\
\hline Linear range, $\mathrm{mol} \mathrm{L}^{-1}$ & $1 \times 10^{-11}-1 \times 10^{-4}$ \\
\hline Limit of detection (LOD), $\mathrm{mol} \mathrm{L}^{-1}$ & $1.6 \times 10^{-10}$ \\
\hline Limit of quantification (LOQ), $\mathrm{mol} \mathrm{L}^{-1}$ & $3.2 \times 10^{-9}$ \\
\hline Regression equation, $\mathrm{Y}^{*}$ & $\mathrm{Y}=\mathrm{a}+\mathrm{bX}$ \\
\hline Intercept (a) & 1.55 \\
\hline Slope (b) & $2.9 \times 10^{9}$ \\
\hline Standard deviation & 0.34 \\
\hline Variance (Sa2) & 8.99 \\
\hline Regression coefficient (r) & 0.9986 \\
\hline
\end{tabular}

*Where $\mathrm{Y}=$ fluorescence intensity, $\mathrm{X}=$ concentration in $\mathrm{n} \mathrm{mol} \mathrm{L}^{-1}, \mathrm{a}=$ intercept, $\mathrm{b}=$ slope.

TABLE 4. Comparison of spectrofluorimetric technique with some existing methods for the determination of bumetanide.

\begin{tabular}{|l|l|l|l|}
\hline \multicolumn{1}{|c|}{ Method } & \multicolumn{1}{|c|}{ Linear range } & $\begin{array}{l}\text { Detection } \\
\text { limit }\end{array}$ & \multicolumn{1}{|c|}{ Ref. } \\
\hline $\begin{array}{l}\text { liquid-chromatography } \\
\text { electrospray time-of-flight mass } \\
\text { spectrometry }\end{array}$ & $3 \times 10^{-12}-3.5 \times 10^{-}$ & $5.8 \times 10^{-10}$ & $\begin{array}{l}\text { [Juan C. D., } \\
\text { et al., 2015] }\end{array}$ \\
\hline Potentiometric method & $1 \times 10^{-6}-1 \times 10^{-3}$ & $3.9 \times 10^{-7}$ & $\begin{array}{l}\text { [El-Tohamy, M. } \\
\text { et al., 2006] }\end{array}$ \\
\hline LC-MS method & $1 \times 10^{-11}-1 \times 10^{-4}$ & $1 \times 10^{-10}$ & $\begin{array}{l}\text { [Deventer, K., } \\
\text { et al., 2002] }\end{array}$ \\
\hline HPLC method & $1 \times 10^{-9}-1 \times 10^{-5}$ & $1 \times 10^{-8}$ & $\begin{array}{l}\text { [Richter, K., } \\
\text { et al., 1996] }\end{array}$ \\
\hline $\begin{array}{l}\text { Spectrofluorimetric method: } \\
\text { Bumetanide-Eu }{ }^{3+} \text {-Acetylacetone }\end{array}$ & $1 \times 10^{-11}-1 \times 10^{-4}$ & $3.2 \times 10^{-9}$ & The present work \\
\hline
\end{tabular}

2. Accuracy and precision of the method: The accuracy and precision computed according to general procedures and the results are given in Table 5 . The relative standard deviation percentage ( $\% \mathrm{RSD}$ ) values were $\leq 2.35 \%$ (intra-day) and $\leq 1.29 \%$ (inter-day) and this indicates that our method is highly precise. Also, the percent of relative error (\%RE) was $\leq 4.0 \%$ (intraday) and $\leq 3.18 \%$ (inter-day) which indicates that our method is highly accurate.

3. Selectivity: Our method was tested for selectivity by studying the effect of placebo blank and synthetic mixture analysis which present with our drug. From the results we found that the recovery percent was $99.50 \pm 0.65,98.9 \pm 1.75$, and $97.60 \pm 0.80$ for tablet, urine, and serum samples, respectively. The results confirmed the accuracy as well as the 
precision of our present method. The results showed that high selectivity was found in case of our drug in present of placebo blank.

4. Application to formulations:Our present method was applied to the determination of bumetanide in pharmaceutical tablets and in serum and urine samples taken from healthy male and female. The results in Table 5 indicated that the present method is very good for the determination of bumetanide. The data represented in Table 6 , were statistically compared with the reference method ${ }^{(35,36)}$. The average recovery percent and R.S.D in our method found to be $(100.2 \pm 1.43 \%),(99.6 \pm 0.70 \%)$, and $(103.1 \pm 1.70 \%)$ for the tablet, serum, and urine samples, respectively. Data obtained by B. P. method showed the average recovery $(99.99 \%, 98.92$ and100.2.) and R.S.D $0.1 \%$ for the tablet, serum, and urine samples, respectively; were also presented for comparison and show a good correlation with those obtained by the present methods. Our results obtained by the present method were found in good agreement with that of the reference method ${ }^{(35,36)}$.

TABLE 5. Evaluation of intra-day and inter-day accuracy and precision.

\begin{tabular}{|c|c|c|c|c|c|c|c|}
\hline \multirow{2}{*}{$\begin{array}{l}\text { Metho } \\
\text { d }\end{array}$} & \multirow{2}{*}{$\begin{array}{c}\text { Bumetanide } \\
\text { Added }(x \\
10^{-7} \mathrm{~mol} \\
\left.\mathrm{~L}^{-1}\right)\end{array}$} & \multicolumn{3}{|c|}{$\begin{array}{c}\text { Intra-day accuracy and } \\
\text { precision }(n=3)\end{array}$} & \multicolumn{3}{|c|}{$\begin{array}{c}\text { Inter-day accuracy and } \\
\text { precision }(n=3)\end{array}$} \\
\hline & & $\begin{array}{c}\text { Bumetanide } \\
\text { average } \\
\text { found } \pm \mathrm{CL}\end{array}$ & $\begin{array}{l}\text { RE } \\
\%\end{array}$ & $\underset{\%}{\text { RSD }}$ & $\begin{array}{c}\text { Bumetanide } \\
\text { average } \\
\text { found } \pm \mathrm{CL}\end{array}$ & $\begin{array}{c}\text { RE } \\
\%\end{array}$ & $\underset{\%}{\text { RSD }}$ \\
\hline Burinex & 10.0 & $10.06 \pm 0.11$ & 1.50 & 0.13 & $10.03 \pm 0.13$ & 0.75 & 1.29 \\
\hline tablets & $\begin{array}{l}5.0 \\
10\end{array}$ & $\begin{array}{l}5.05 \pm 0.17 \\
1.20+0.23\end{array}$ & $\begin{array}{l}0.83 \\
250\end{array}$ & 1.12 & $\begin{array}{l}4.95 \pm 0.18 \\
19+0.24\end{array}$ & $\begin{array}{l}0.83 \\
2.37\end{array}$ & $\begin{array}{l}1.23 \\
1.19\end{array}$ \\
\hline Urine & 10.0 & $10.16 \pm 0.23$ & 4.00 & 2.22 & $9.99 \pm 0.30$ & 2.19 & 0.16 \\
\hline sample & $\begin{array}{l}5.0 \\
1.0\end{array}$ & $\begin{array}{l}5.05 \pm 0.28 \\
1.19 \pm 0.48\end{array}$ & $\begin{array}{l}0.83 \\
2.37\end{array}$ & $\begin{array}{l}1.86 \\
2.35\end{array}$ & $\begin{array}{l}5.04 \pm 0.41 \\
1.03 \pm 0.31\end{array}$ & $\begin{array}{l}3.18 \\
1.59\end{array}$ & $\begin{array}{l}0.13 \\
0.12\end{array}$ \\
\hline Serum & 10.0 & $9.99 \pm 0.11$ & 0.25 & 1.11 & $10.11 \pm 0.13$ & 2.75 & 1.26 \\
\hline sample & $\begin{array}{l}5.0 \\
1.0\end{array}$ & $\begin{array}{l}5.04 \pm 0.16 \\
1.13 \pm 0.21\end{array}$ & $\begin{array}{l}0.66 \\
1.62\end{array}$ & $\begin{array}{l}1.06 \\
1.02\end{array}$ & $\begin{array}{l}5.02 \pm 0.18 \\
0.98 \pm 0.26\end{array}$ & $\begin{array}{l}0.33 \\
1.37\end{array}$ & $\begin{array}{l}1.21 \\
1.15\end{array}$ \\
\hline
\end{tabular}

\%RE: percent relative error, \%RSD: relative standard deviation and CL: confidence limits were calculated from: $C L= \pm t S \sqrt{ }$. (The tabulated value of $t$ is 4.303 , at the $95 \%$ confidence level; $S=$ standard deviation and $n=$ number of measurements.)

\section{Recovery study}

From the results of studding the recovery percentage for our proposed method (Table 7) we found that the values of recovery $\%$ for tablet, urine, and serum samples, ranged between (99.75 and $102.09 \%), 103.85 \%)$, and $(97.00$ and $100.20 \%)$ with relative standard deviation in the range $(0.25-$ $0.69 \%),(0.61-0.85 \%)$, and $(0.25-1.15 \%)$ respectively. Closeness of the results to $100 \%$ showed the fairly good accuracy of the proposed methods. 
TABLE 6. Results of analysis of tablets by the proposed method and statistical comparison of the results with the reference method.

\begin{tabular}{|c|c|c|c|c|c|}
\hline \multirow{3}{*}{$\begin{array}{l}\text { Tablet } \\
\text { brand } \\
\text { name }\end{array}$} & \multirow{3}{*}{$\begin{array}{c}\text { Nominal } \\
\text { amount, } \\
\text { Added } \\
\left(\begin{array}{ll} & 10^{-7} \\
\left.\text { mol L }^{-1}\right)\end{array}\right.\end{array}$} & \multicolumn{4}{|c|}{ Found $\left(\right.$ Percent \pm SD) ${ }^{b}$} \\
\hline & & \multirow[b]{2}{*}{ Reading } & \multirow{2}{*}{ 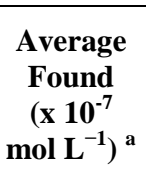 } & \multirow{2}{*}{$\begin{array}{l}\text { B.P. } \\
\text { (LC) }\end{array}$} & $\begin{array}{c}\text { Proposed } \\
\text { method }\end{array}$ \\
\hline & & & & & $\begin{array}{c}\text { Recovery } \\
\pm \operatorname{RSD}(\%)\end{array}$ \\
\hline $\begin{array}{l}\text { Burinex } \\
\text { tablets }\end{array}$ & $\begin{array}{c}5 \\
1 \\
0.1\end{array}$ & $\begin{array}{c}5.09,4.99,5.13 \\
1.06,1.11,0.99 \\
0.09,0.13,0.088\end{array}$ & $\begin{array}{c}5.13 \\
1.05 \\
0.103\end{array}$ & $99.99 \pm 0.39$ & $100.2 \pm 1.43$ \\
\hline $\begin{array}{l}\text { Urine } \\
\text { sample }\end{array}$ & $\begin{array}{c}5 \\
1 \\
0.1\end{array}$ & $\begin{array}{c}5.19,5.09,4.92 \\
0.98,1.11,0.96 \\
0.08,0.13,0.097\end{array}$ & $\begin{array}{c}5.07 \\
1.02 \\
0.102\end{array}$ & $100.2 \pm 0.1$ & $103.1 \pm 1.70$ \\
\hline $\begin{array}{l}\text { Serum } \\
\text { sample }\end{array}$ & $\begin{array}{c}5 \\
1 \\
0.1\end{array}$ & $\begin{array}{c}5.0,5.09,4.92 \\
1.0,1.11,0.96 \\
0.13,0.10,0.087\end{array}$ & $\begin{array}{l}5.00 \\
1.02 \\
0.106\end{array}$ & $98.92 \pm 2.2$ & $99.6 \pm 0.70$ \\
\hline
\end{tabular}

$a$, each reading was repeated three times (average was taking for three reads by three analysts) $b$, Average of three determinations.

5

TABLE 7. Results of recovery study using standard addition method.

\begin{tabular}{|c|c|c|c|c|}
\hline \multicolumn{5}{|c|}{ Proposed method } \\
\hline $\begin{array}{l}\text { Tablet } \\
\text { studied }\end{array}$ & $\begin{array}{c}\text { Bumetanide } \\
\text { in tablet } \\
\text { extract, } x 1^{-7} \\
\text { mol } \mathrm{L}^{-1}\end{array}$ & $\begin{array}{c}\text { Pure } \\
\text { Bumetanide } \\
\text { added, } x \mathbf{1 0}^{-7} \\
\text { mol L } \mathbf{L}^{-1}\end{array}$ & $\begin{array}{c}\text { Total } \\
\text { Bumetanide } \\
\text { found, } \times \mathbf{~ 1 0}^{-7} \\
\text { mol L L }^{-1}\end{array}$ & $\begin{array}{c}\text { Pure Bumetanide } \\
\text { recovered } \\
(\text { Percent } \pm \text { SD })\end{array}$ \\
\hline \multirow{3}{*}{ Tablet } & 10 & 1.5 & 11.40 & $99.75 \pm 0.25$ \\
\hline & 1.0 & 3.0 & 3.95 & $98.75 \pm 0.45$ \\
\hline & 0.1 & 4.5 & 4.65 & $102.09 \pm 0.69$ \\
\hline \multirow{3}{*}{$\begin{array}{c}\text { Urine } \\
\text { sample }\end{array}$} & 10 & 1.5 & 11.38 & $98.96 \pm 0.61$ \\
\hline & 1.0 & 3.0 & 4.15 & $103.85 \pm 0.75$ \\
\hline & 0.1 & 4.5 & 4.43 & $97.33 \pm 0.85$ \\
\hline \multirow{3}{*}{$\begin{array}{l}\text { Serum } \\
\text { sample }\end{array}$} & 10 & 1.5 & 11.46 & $99.65 \pm 1.15$ \\
\hline & 1.0 & 3.0 & 3.92 & $97.0 \pm 0.35$ \\
\hline & 0.1 & 4.5 & 4.61 & $100.2 \pm 0.25$ \\
\hline
\end{tabular}

\section{Conclusion}

Complex $1\left(\mathrm{Eu}^{3+}\right.$-Acetylacetone complex $)$ in the presence of bumetanide has high sensitivity and characteristic peaks. The peaks intensities are 
enhanced by increasing the concentration of bumetanide, due to energy transfer from bumetanide to the Europium ion and can be used for bumetanide determination in biological fluids and pharmaceutical preparations with high accuracy.

\section{References}

1. Delgado, J. N., Remers, W. A., Textbook of Organic Medicinal and Pharmaceutical Chemistry, 9th ed., J. B. Lippincot: Philadelphia, (1991).

2. Shinto, R. A. and Light, R. W., Am. J. Med., 88, 230, (1990).

3. Kristensen, B. O. and Show, J., Lancet, 2, 699, (1980).

4. Ventura, R. and Segura, J., J. of Chromatogr., B, 687, 127, (1996).

5. International Olympic Committee; Medical Commission, International Olympic Charter against Doping in Sport, IOC: Lausanne, (1990).

6. Ruiz-Angel, M. J., Berthod, A., Carda-Broch, S. and Álvarez-Coque, M. C. G., Separation \& Purification Reviews, 35, 39, (2006).

7. Shaikh, B., In Veterinary Drug Residues-Diuretic Drugs Used in Food Producing Animals; Moats, W. A.; Medina, M. B., Ed.; ACS Symposium Series 636, American Chemical Society: Washington, (1996).

8. British Pharmacopoeia Her Majesty' s Stationery Office, London, (1998).

9. Ferraro, M., Castellano, P. and Kaufman, T., J. of Pharm. Biomed. Anal., 26, $443,(2001)$.

10. García-Sánchez, F., Fernández-Gutiérrez, A. and Cruces-Blanco, C., Anal. Chim. Acta, 306, 313, (1995).

11. Luis, M. L., Fraga, J. M. G., Jiménez, A. I., Jiménez, F., Hernández, O. and Arias, J. J., J. Talanta, 62, 307, (2004).

12. Ioannou, P. C., Rusakova, N. V., Andrikopoulou, D. A., Glynoy, K. M. and Tzompanaki, G. M., Analyst, 123, 2839, (1998).

13. Nicolic, K. I. and Medenica, M., Acta, Pharm. J., 40, 521, (1990).

14. Barroso, M. B., Alonso, R. M. and Jiménez, R. M., Anal. Chim. Acta, 305, 332, (1995).

15. United States Pharmacopeia, USP 24: Rockville, (2000).

16. El-Saharty, Y. S., J. of Pharm. Biomed. Anal., 33, 699, (2003).

17. Baranowskaa, I., Markowski, P. and Baranowski, J., Anal. Chim. Acta, 570, 46, (2006). 
18. Yuan, J. and Matsumoto, K., Anal. Sci. 12, 31, (1996).

19. Azab, H., El-Korashy, S., Anwar, Z.M., Hussein, B.H.M. and Khairy, G.M., Spectro- chim. Acta A. Mol. Biomol. Spectrosc. 75, 21, (2010).

20. Gusev, A.N., Hasegawa, M., Shimizu, T., Fukawa, T., Sakurai, S., Nishchymenko, G. A., Shul' gin, V. F., Meshkova, S. B. and Linert, W., Inorg. Chim. Acta, 406, 279-284, (2013).

21. Reddy, K. H., M., Reddy, R., Mohana, K. R., Polyhedron, 16, 15, 2673-2679, (1997).

22. Maurya, R. C. and Rajput, S., J. of Mol. Struct., 833, 133, (2007).

23. Gudasi, K. B.; Shenoy, R. V.; Vadavi, R. S. and Patil, S. A., Trans Met. Chem. 31, 374, (2006).

24. Narang, K.K. and Singh, V.P., Trans. Met. Chem., 2, 507, (1996).

25. Refat, M. S., Al-Azab, F. M., Al-Maydama, H. M. A., Amin, R. R. and Jamil, Y. M. S., J. of Mol. Struct., 1059, 208- 224, (2014).

26. Nibha, Kapoor, I.P.S., Singh, G. and Frohlich, R., J. of Mol. Struct., 1034, 296-301, (2013).

27. Abd-Elzaher, M. M. and Fischer, H., J. Organometal. Chem., 588, 2, 35-241, (1999).

28. Abd-Elzaher, M. M., Moustafa, S. A., Labib, A. A., Mousa, H. A., Ali, M. M. and Mahmoud, A. E., Appl. Organometal. Chem., 26, 230- 236, (2012).

29. Abd-Elzaher, M. M., Appl. Organometal. Chem., 18, 149- 155, (2004).

30. Abd-Elzaher, M. M., Hegazy, W. H. and Gaafar, A. M., Appl. Organometal. Chem., 19, 911-916, (2005).

31. Attia, M. S., Diaba, M. and El-Shahat, M. F., Sensors and Actuators, B, 207, 756- 763, (2015).

32. Azab, H. A., Anwar, Z. M., Rizk, M. A., Khairy, G. M. and El-Asfoury, M. H., J. of Lumin. 157, 371- 382, (2015).

33. International Conference on Hormonisation of Technical Requirements for Registration of Pharmaceuticals for Human Use, ICH Harmonised Tripartite Guideline, Validation of Analytical Procedures: Text and Methodology $Q 2(R \quad 1)$, Complementary Guideline on Methodology dated 06 November (1996), incorporated in November (2005).

34. Michael, H. W., Yunhui, W., Tsang-Lin, H., Xue-Zhi, Q., Shyam, K. and Varaporn, T., J. Chromatogr. B; 810(2), 209-219, (2004). 
35. British Pharmacopoeia, vol. II, Her Majesty's Stationary Office, London, p.2705, (1999).

36. The United States Pharmacopeia xxv, United States Pharmacopeial Convention, Inc., 12061, Twinbrook Parkway, Rockville, MD 20852, (2002).

37. Cho, I., GillKang, J. and Sohn, Y., J. of Lumin. 157, 264- 274, (2015).

38. Gaspar, D., Freire, J. M., Pacheco, T. R., Barata, J. T. and Castanho, M., Biochimica et Biophysica Acta, 1853, 308- 316, (2015).

39. Goel, N., J. of Mol. Struct., 1080, 1- 7, (2015).

40. Martinez, E., Sevillano, J., Cussó, F. B. and Oca‘A. M., J. of Alloys and Compounds, 619, 44-51, (2015).

41. Martins, J. P., Ramos, P., Coya,C., Silva, M., Eusebio, M. Andrés, A., Álvarez, Á. and Gil, J. M., J. of Lumin. 159, 17-25, (2015).

42. Masuya, A., Igarashi, C., Kanesato, M., Hoshino, H. and Iki, N., Polyhedron, 85, 76-82, (2015).

43. Zhao, M., Tang, R. and Xu, S., Spectrochimica Acta Part A: Molecular and Biomolecular Spectroscopy, 135, 953-958, (2015).

(Received; accepted) 
مخلص محمد عبد الظاهر" ، منى عبد العزيز أحمد*** ، عبد الفتاح بسطاوى

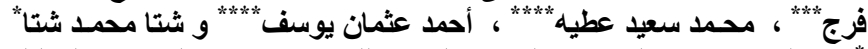

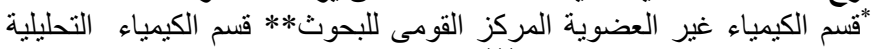

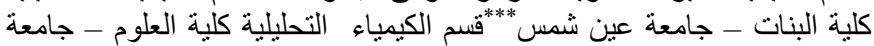
حلوان - ق******م الكيمياء غير العضوية كلية العلوم - جامسعة عين شمس -

فى هذا البحث تم تحضير متر اكب رقم 1 من تفاعل الاسيتل اسيتون مع الاربييوم

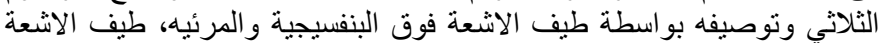

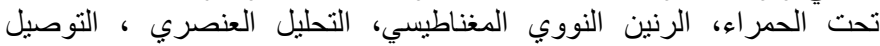

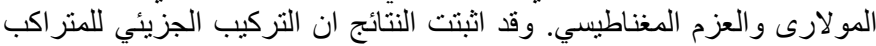

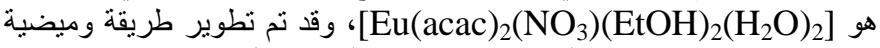

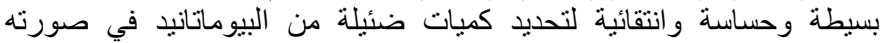

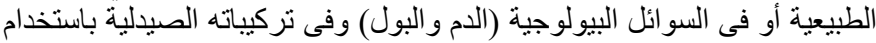

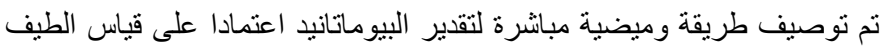

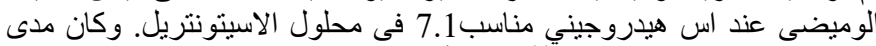

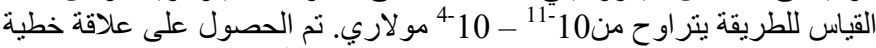

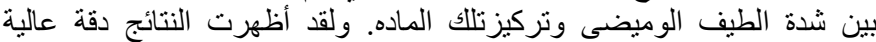

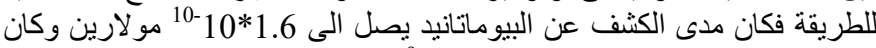
مدى تقدير هذه الماده يصل الى 3.2 * 10 19 